\title{
Constitutive Equations for the Nonlinear Viscoelastic Phenomena in Concentrated Polymer Systems. Part I.
}

by

\author{
Masaoki TAKAhashi and Shigeharu ONogi \\ (Department of Polymer Chemistry, Kyoto University, Kyoto)
}

\begin{abstract}
A critical review of the recent phenomenological and experimental studies on the nonlinear viscoelastic phenomena in concentrated polymer systems is presented. Differential type constitutive equations are classified into three groups: the extension of the 3-dimensional linear Maxwell model, of the Jeffreys model and of the constitutive equation for general viscous fluid. Applicability and limitations of these equations are discussed. On the other hand, integral type constitutive equations are classified into two groups: multi-integral expansion type and approximate closed form type equations.

The last type equations are classified further into two groups: the one time $\left(t^{\prime}\right)$-single integral type (WJFLMB, Bird-Carreau, Yamamoto, BKZ, special forms of BKZ) and the two times $\left(t^{\prime}\right.$, $t^{\prime \prime}$ )-single integral type (Carreau, Yamamoto, Takahashi-Masuda-Onogi). The memory function in the one time $\left(t^{\prime}\right)$-single integral type constitutive equation depends on the invariants of either the rate of strain tensor at $t^{\prime}$ or the relative strain tensor between $t^{\prime}$ and $t$. It cannot express the depenc'ences of relaxation times on the rate of strain or the relative strain. The memory function in the two times $\left(t^{\prime}, t^{\prime \prime}\right)$-single integral type constitutive equation includes the time $\left(t^{\prime \prime}\right)$ integration of the function of the invariants of either the rate of strain tensor at $t^{\prime \prime}\left(t^{\prime} \leqq t^{\prime \prime} \leqq t\right)$, the stress tensor at $t^{\prime \prime}$, or the relative strain tensor between $t^{\prime \prime}$ and $t^{\prime}$. It can express the dependences of relaxation times on the rate of strain, relative strain or stress.

Comparisons between recent experimental results and the predictions of the two times $\left(t^{\prime}\right.$, $\left.t^{\prime \prime}\right)$-single integral type constitutive equations for specific flows (steady shear flow, stress overshoot, and interrupted flow) are discussed in detail. Among others, it is emphasized that the integral type constitutive equations with either the rate of strain or the relative strain dependent memory function cannot explain the recent experimental data obtained by van Es and Christensen.
\end{abstract}

\section{高分子濃厚系の非線形粘弾性現象と構成方程式〔I}

$$
\text { 高 橋 雅 興・小野木重治* }
$$

（原稿受理：1974年 9 月 6 日）

\section{1. 緒}

言

“最近，高分子濃厚溶液あるいは溶融物（高分子濃厚系）の非定 常状態における非線形粘弾性現象が，特に注目されつつある ${ }^{122)}$. このような現象としては，せん断流動（せん断速度一定）開始時 の応力成長（ストレス・オーバーシュート）と流動停止後の応力 緩和，大変形（せん断ひずみ一定）下における応力緩和，さらに

\footnotetext{
* 宗都大学工学部高分子化学教室 宗都市左宗区占四本町
}

一軸伸長流動（ひずみ速度一定）開始時の応力成長などがあげら れる.

てれらの現象を解析するととにより，高分子鎖のからみ合いに よって形成される網目構造が変形を受けて示す変化を解明するた めの有力な情報が得られる。しかし, 線形粘弾性の場合と異なっ て, 非線形粘弾性現象に対する現象論がまだ十分には確立されて いないために，それらの現象の解析方法が定まって抢らず，解析 した結果の一意的な分子論的解勫も非常に困難であるのが現状で ある。 
この総説は，以上のような背景をふまえて，現在までに行なわ れた高分子濃厚系の非線形粘弾性現象に関する現象論的研究と実 験的研究とを総合的に検討・評価して問題点を明らかにするとと によって，将来の現象論の発展と確立に寄与するとともに将来行 なわれるべき分子論的研究を鼓舞するてとを目的としている。

工業上重要な高分子の加工（プラスチックスの成形加工, 繊維 の紡糸など）の複雑なレオロジ一的過程が，ほとんどすべて非線 形で非定常の力学現象であるととを考えると, 本総説で取り扱う ような基礎的な研究が，乙れら実際の場における複雑なレオロシ 一的過程の解析にとっても, 不可欠かつ重要な研究であると考え る.

\section{2. 構 成 方 程 式}

物体の応力とひずみの間の一般的な関係を記述し， 3 次元的な 非線形粘弾性現象を統一的に表わすべき式を，構成方程式 (constitutive equation) あるいはレオロジー状態方程式 (rheological equation of state) という。等温条件下における，等方性で非圧 縮性の物体に対して, 現在までに提出された構成方程式は, 次の ように大別できる ${ }^{3) ~ 8) . ~}$

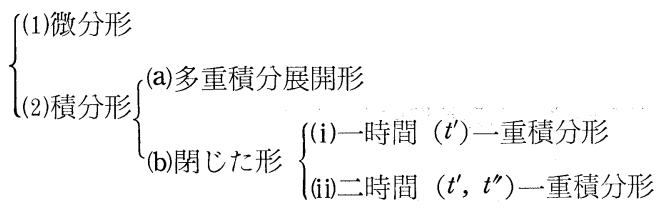

積分形の構成方程式のうち, 多重積分展開形とは, 変形（相対 ひずみテンソル）の時間相関に関して二重積分以上の多重時間積 分を含むものと定義し, 閉じた形とは, 変形の時間相関に関して 一重積分にとどめ，記憶関数の形を工夫したものと定義する．以 下の記述は, 特にてとわらない限り, すべて直交デカルト空間座 標系 (固定座標系) ${ }^{* 1}$ で表現する。

\section{$2 \cdot 1$ 微分形の構成方程式}

微分形の構成方程式は，そのほとんどすべてが， 3 次元線形 Maxwell 要素の構成方程式, Jeffreys の構成方程式あるいは粘 性流体の構成方程式のどれかの拡張になっている。例をあげれば 次のようになる.

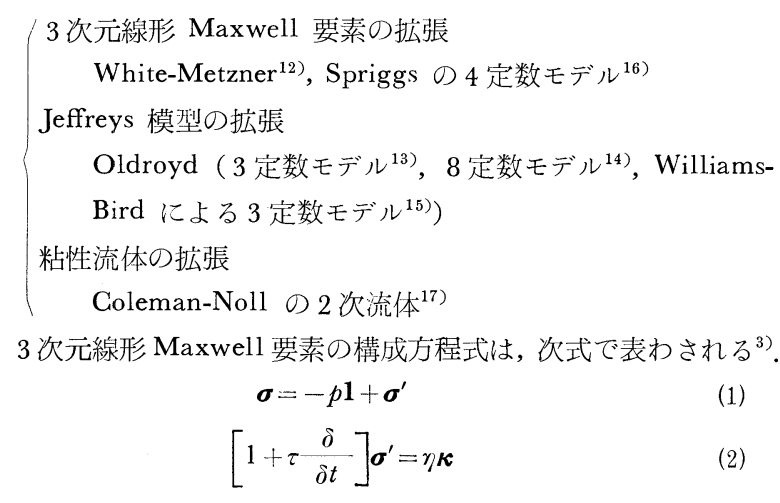

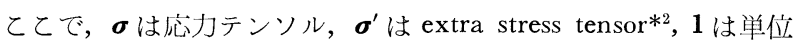

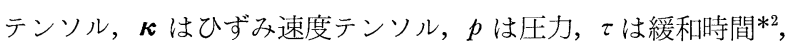

*1 座標系には, 物体座標系, 空間座標系, コンベクテッド (convected) 座標系の三つがある。空間座標系は固定座標系であ り, 物体座標系とコンベクテッド座標系は物体之共に動く座標系 である。これら三つの座標系の間の変換については，Lodge の著

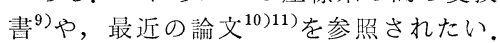

$\eta(=G \tau)$ は粘度である。 $\boldsymbol{v}$ を着目した質点の空間に対する速度,

$\boldsymbol{\nabla}$ を勾配 (grad) として， $\boldsymbol{\kappa}$

$$
\boldsymbol{\kappa}=\boldsymbol{\nabla} \boldsymbol{v}+(\boldsymbol{\nabla} \boldsymbol{v})^{T}
$$

で定義される*3．T は転置の記号である， $\boldsymbol{x}=\left(x_{1}, x_{2}, x_{3}\right)$ を固定 座標系で表わした質点の位置座標として, $\boldsymbol{\nabla} \boldsymbol{v} の ~ i j$ 成分 $(\boldsymbol{V} \boldsymbol{v})_{i j}$ は,

$$
(\boldsymbol{V} \boldsymbol{v})_{i j}=\left[\left(\frac{\partial}{\partial \boldsymbol{x}}\right)^{T} \boldsymbol{v}\right]_{i j}=\frac{\partial v_{j}}{\partial x_{i}}
$$

で与えられる*4. $\delta(\quad) / \delta t$ は Oldroyd ${ }^{13)}$ によって導入されたコ ンベクテッド導関数 (convected derivative) であり, $\boldsymbol{A}$ を対称テ ンソルとして,

$$
\frac{\delta \boldsymbol{A}}{\delta t}=\frac{D \boldsymbol{A}}{D t}-(\boldsymbol{\nabla} \boldsymbol{v})^{T} \cdot \boldsymbol{A}-\boldsymbol{A} \cdot(\boldsymbol{\nabla} \boldsymbol{v})
$$

で与えられる ${ }^{3) 9} * 5$. ここで， $D(\quad) / D t$ は物質導関数 (material derivative $)^{* 6}$ と呼ばれ，物体と共に動く観測者が物体中の同一の 実質部分に着目して見たときの時間変化を表わしており， $\boldsymbol{a}_{i}$ をテ ンソル $\boldsymbol{A}$ の第 $i$ 行を成分とするベクトル， $\hat{\boldsymbol{x}}$ を着目した質点のコ ンベクテッド座標, $t$ を時間として,

$$
\begin{aligned}
& \frac{D a_{i}(\boldsymbol{x}(\hat{\boldsymbol{x}}, t), t)}{D t}=\left[\frac{\partial \boldsymbol{a}_{i}(\boldsymbol{x}(\hat{\boldsymbol{x}}, t), t)}{\partial t}\right]_{\hat{\boldsymbol{x}}} \\
= & \left(\frac{\partial a_{i}}{\partial t}\right)_{\boldsymbol{x}}+\left(\frac{\partial \boldsymbol{x}}{\partial t}\right)_{\hat{\boldsymbol{x}}} \cdot\left(\frac{\partial}{\partial \boldsymbol{x}}\right)^{T} \boldsymbol{a}_{i}
\end{aligned}
$$

から，

$$
\frac{D \boldsymbol{A}}{D t}=\frac{\partial \boldsymbol{A}}{\partial t}+\boldsymbol{v} \cdot \boldsymbol{\nabla} \boldsymbol{A}
$$

で与えられる。ただし

$$
\boldsymbol{v}=\left(\frac{\partial \boldsymbol{x}}{\partial t}\right)_{\hat{\boldsymbol{x}}}=\frac{D \boldsymbol{x}}{D t}
$$

を使った，式(7)は次のととを意味している。すなわち, 空間に静

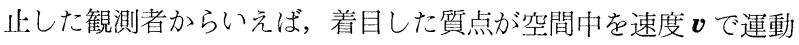
しているための見掛けの変化 $(\boldsymbol{v} \cdot \boldsymbol{\nabla} \boldsymbol{A})$ も観測するてとになる3 ${ }^{399)}$. $\delta() / \delta t$ は次のように書きかえるととができ，乙れを $\partial_{t}(1,0,0)$ ( ) と定義する ${ }^{3)}$.

$$
\begin{gathered}
\partial_{t}(1,0,0) \boldsymbol{A}=\frac{\delta \boldsymbol{A}}{\delta t}=\frac{D \boldsymbol{A}}{D t}-\boldsymbol{\omega} \cdot \boldsymbol{A}+\boldsymbol{A} \cdot \boldsymbol{\omega} \\
-\frac{1}{2}(\boldsymbol{\kappa} \cdot \boldsymbol{A}+\boldsymbol{A} \cdot \boldsymbol{\kappa})
\end{gathered}
$$

ここで， $\boldsymbol{\omega}$ は着目した質点を含む物体の微小部分の, 空間に対す る回転を表わす vorticity tensor であり，

*2 extra stress tensor を $\tau$, 緩和洔間を $\lambda$ と書くことも多いが, ここではこのように表わすととにする。また，偏差応力 $\boldsymbol{\sigma}^{\prime \prime}$ は, $\boldsymbol{\sigma}^{\prime \prime}=\boldsymbol{\sigma}^{\prime}-(1 / 3)\left(\operatorname{Tr} \boldsymbol{\sigma}^{\prime}\right) \mathbf{1}=\boldsymbol{\sigma}-(1 / 3)(\operatorname{Tr} \boldsymbol{\sigma}) \mathbf{1}$ で定義される。 $T r$ は対角成分の和をとるととを表わす。 $\operatorname{Tr} \boldsymbol{\sigma}^{\prime}=0$ のとき， $\boldsymbol{\sigma}^{\prime \prime}=\boldsymbol{\sigma}^{\prime}$ となる。

*3 ひずみ速度テンソルには， $\boldsymbol{A}, \boldsymbol{A}, \boldsymbol{A}_{1}$ などの記号が使われる ととも多い.また, 式(3)の右辺の $1 / 2$ 倍をひずみ速度テンソル $(\boldsymbol{e}$, $\boldsymbol{E}, \boldsymbol{D}$ などの記号が使われる）上定義するととも多い99.

*4 習慣的飞 $(\boldsymbol{V} \boldsymbol{v})_{i j}=\partial v_{i} / \partial x_{j}$ と定義するてとああるが，乙の定 義は正しくない。なお， $\boldsymbol{\nabla} \boldsymbol{v},(\partial / \partial \boldsymbol{x})^{T} \boldsymbol{v}$ などはダィアディックスで ある。

*5 式(5)は, テンソル $\boldsymbol{A}$ を一般化座標において反変成分で表現す ときの定義であって, 共変成分で表現するときは, $\delta \boldsymbol{A} / \delta t=D \boldsymbol{A} /$ $D t+(\boldsymbol{\nabla} \boldsymbol{v}) \cdot \boldsymbol{A}+\boldsymbol{A} \cdot(\boldsymbol{\nabla} \boldsymbol{v})^{T}$ となる。 乙のように, $\delta() / \delta t$ は直交デ カルト座標系を使用する場合でも二つの定義のし方があるので汗 意を要する.

*6 実啠導関数 (substantial or intrinsic derivative) とも呼ばれ る. $D() / D t$ を $d() / d t$ と書くこともある. 


$$
\boldsymbol{\omega}=-\frac{1}{2}\left[\boldsymbol{\nabla} \boldsymbol{v}-(\boldsymbol{\nabla} \boldsymbol{v})^{T}\right]
$$

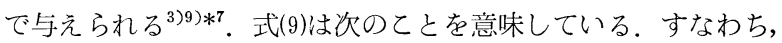
空間に静止した観測者からみた $\boldsymbol{A}$ の時間的な変化には, 物体の

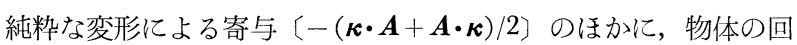
転による見掛けの $\boldsymbol{A}$ の変化 $(-\boldsymbol{\omega} \cdot \boldsymbol{A}+\boldsymbol{A} \cdot \boldsymbol{\omega})$ も含まれている 9). $\delta($ ) $/ \delta t$ のうち, 純粋な変形による寄与を除いた部分は, Jaumann derivative $\mathfrak{D}() / \mathscr{D} t$ と呼ばれ

$$
\frac{\mathfrak{D} \boldsymbol{A}}{\mathfrak{D} t}=\frac{D \boldsymbol{A}}{D t}-\boldsymbol{\omega} \cdot \boldsymbol{A}+\boldsymbol{A} \cdot \boldsymbol{\omega}
$$

で与えられる9 .

式(2)を拡張するにあたっては， $a, b$ および $c$ を無次元パラメー ターとする次のような時間微分演算子 $\partial_{t}(a, b, c)$ が導入される ${ }^{334)}$.

$$
\begin{aligned}
\partial_{t}(a, b, c) \boldsymbol{A} & =\frac{\mathfrak{D} \boldsymbol{A}}{\mathfrak{D} t}-\frac{a}{2}(\boldsymbol{\kappa} \cdot \boldsymbol{A}+\boldsymbol{A} \cdot \boldsymbol{\kappa}) \\
& +\frac{b}{2} \operatorname{Tr}(\boldsymbol{\kappa} \cdot \boldsymbol{A}) \mathbf{1}+\frac{c}{2}(\operatorname{Tr} \boldsymbol{A}) \boldsymbol{\kappa}
\end{aligned}
$$

ここで， $\operatorname{Tr}$ は対角成分の和をとることを表わす，Jeffreys 模型 を 3 次元に搪張した構成方程式の一つは，式(2)の $\eta$ を $\eta_{0}[1+\lambda \delta /$

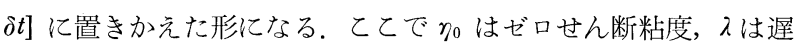
延時間である. White-Metzner モデル ${ }^{12)}$ は, 式(2)の $\tau$ とクが $\boldsymbol{~} の$ 不変量の関数としたものである.また Oldroyd の8 定数モデ $ル^{14)}$ は，式(2)の $\delta / \delta t$ を $\partial_{t}(a, b, c)$ にか光， $\eta$ を $\eta_{0}\left[1+\lambda \partial_{t}(d, e\right.$, 0)了に置きかえたものである.たいていの場合，てのモデルはパ ラメーターの数を減らして, 式(2)の $\delta / \delta t$ を $\partial_{t}(1,2 / 3,0)$ とし, $\eta$ を $\eta_{0}\left\{1+\lambda \partial_{t}(1,2 / 3,0) 〕\right.$ とした 3 定数モデル ${ }^{15) * 8}$ として使用さ れる. Spriggs の 4 定数モデル ${ }^{16)}$ は，式(2)つ $\delta / \delta t$ を $\partial_{t}(1+\varepsilon, 2$ $(1+\varepsilon) / 3,0)$ 亿かえた式が各緩和機構について成立するとし， $\boldsymbol{\sigma}^{\prime}$ が各緩和機構からの寄与の和 $\left(\sum_{i} \sigma_{i}{ }^{\prime}\right)$ で与られるとして, 緩和 時間の分布を導入したものである. こてでをは, 単純せん断流動 における副法線応力差がゼロであるとするワイセンベルグの仮説 からのずれを表わすパラメーターである.

一般の粘性流体の構成方程式は， $\alpha$ および $\beta$ を $\boldsymbol{\kappa}$ の不変量の関 数として,

$$
\boldsymbol{\sigma}^{\prime}=\alpha \boldsymbol{\kappa}+\beta \boldsymbol{\kappa} \cdot \boldsymbol{\kappa} .
$$

で表わされる ${ }^{32}$. Coleman-Noll の 2 次流体 ${ }^{17)}$ と呼ばれるものは，

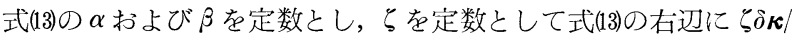
$\delta t$ を加えたものである. 一般に, 式(13)を拡張した微分形の構成 方程式で, 応力の時間微分を含まないものは，ひずみ一定の応力 緩和を説明できず，式(2)を拡張したものに比べて適用範囲が狭い．

\section{$2 \cdot 2$ 微分形の構成方程式の適用性について}

微分形の構成方程式は, 次の三つの点で積分形のものほど便利 でないと考えられる5)18).

（1）緩和スペクトルとして不連続な線スペクトルしか導入でき ない。

（2）応力の成分についての6 個の連立微分方程式を解くとき， 一般に掑動法あるいは数值解法によらなければ計算できない。

（3）微分方程式の解が発散したり，不合理な值になったりする ことがある。

$\overline{* 7 \quad(\boldsymbol{V} \boldsymbol{v})_{i j}=\partial v_{i} / \partial x_{j}}$ と定義するときは, $\boldsymbol{\omega}=(1 / 2)\left[\boldsymbol{\nabla} \boldsymbol{v}-(\boldsymbol{\nabla} \boldsymbol{v})^{T}\right]$ と なる。なお, Bird ら ${ }^{38)}$ は $(\boldsymbol{V} \boldsymbol{v})_{i j}=\partial v_{j} / \partial x_{i}$ として, $\boldsymbol{\omega}$ 在 $\boldsymbol{\omega}=\boldsymbol{\nabla} \boldsymbol{v}$ $(\boldsymbol{\nabla} \boldsymbol{v})^{T}$ と定義している.

*8 式(2)の $\delta / \delta t$ をそのままとし， $\eta$ を $\eta_{0}[1+\lambda \delta / \delta t]$ としたモデ ル ${ }^{13)} 3$ 定数モデルと呼ぶことすある.
また，微分形の構成方程式にはひずみテンソルが含まれておら ず，ひずみ速度テンソルとその不変量だけが用いられている。 そ のため, 微分形の構成方程式では, ひずみが時間と共䎲なめらか に変化する変形様式は記述できるが，ひずみがある時刻で不連続 的に変化する変形様式（例えば大変形下の応力緩和）の記述は一 般に困難であるか不能である．同様のととが，後に述べるひずみ 速度依存形の積分形構成方程式についてもいえる。

微分形の構成方程式は，単純せん断流動では一般に積分形のも のに比べ実験結果との一致は覀いが ${ }^{19)}$ 22)，単純せん断以外の流 動, 例えば伸長流動 (一軸伸長流動 ${ }^{21)}$, 二軸伸長流動 ${ }^{23)}$ ) や $\mathrm{T}$ 字 形スリットでの stagnation flow $^{22)}$ などでは, 積分形のものより むしろよく実験結果を定量的にも再現するととがある.

高分子濃厚系の円管流動，バラス効果，不安定流動とメルトフ ラクチュアなどのレオロジ一的現象の解析には, 積分形の構成方 程式よりもむしろ微分形の構成方程式の方がよく用いられる。 こにあげた例のように, 物体全体の外力分布と変形との間の関係 が問題になるときには, 連続の式 (質量の保存則), 運動方程式 (運動量の保存則)，エネルギー方程式（エネルギーの保存則）お よび構成方程式（物体の各微小部分の応力とひずみの間の関係） の四つの方程式を連立して解くことになるが335)24), 前三者が微 分形で表現されており，てれらと微分形の構成方程式のどれかと を連立させて適当な境界条件のもとに解くというのが，てういう 問題を取り扱うときの最もオーソドックスな手法である。もちろ ん，積分形の構成方程式を使うとともできる．とのような実際的 な問題への応用は，次回分の最後にまとめて述べるととにする。

\section{$2 \cdot 3$ 積分形の構成方程式}

\section{$2 \cdot 3 \cdot 1$ 多重積分展開形の構成方程式}

多重積分展開形の構成方程式は，Truesdell-Noll ${ }^{25)}$, ColemanNoll $\left.{ }^{26)} 28\right)$, Green-Rivlin ${ }^{29) ~ 31)}$, Pipkin $^{32)}$ らによって3 次元的 に取り扱われ，中田 ${ }^{33}$ により1次元的な取り扱いが行なわれた。 Goleman-Noll らによれば, 減衰記憶*9 をつつ単純流体 (simple fluid) $* 10$ の構成方程式は, 次のような多重積分展開形として表わ せる。

$$
\begin{gathered}
\boldsymbol{\sigma}(t)=-p \mathbf{1}+\int_{-\infty}^{t} \mu_{(1)}\left(t-t^{\prime}\right) \boldsymbol{\Gamma}\left(t^{\prime}\right) d t^{\prime}+\int_{-\infty}^{t} \int_{-\infty}^{t}\left\{\mu_{(2)}\left(t-t^{\prime}, t-t^{\prime \prime}\right)\right. \\
\left.\boldsymbol{\Gamma}\left(t^{\prime}\right) \cdot \boldsymbol{\Gamma}\left(t^{\prime \prime}\right)+\mu_{(3)}\left(t-t^{\prime}, t-t^{\prime \prime}\right)\left[\operatorname{Tr} \boldsymbol{\Gamma}\left(t^{\prime}\right)\right] \boldsymbol{\Gamma}\left(t^{\prime \prime}\right)\right\} d t^{\prime} d t^{\prime \prime}
\end{gathered}
$$

ことで， $t$ は現時刻 (応答時刻)， $t^{\prime}, t^{\prime \prime}, \cdots \cdots$ は過去の時刻（刺激 時刻) であり, $\mu_{(1)}, \mu_{(2)}, \mu_{(3)}, \cdots \cdots$...核関数 (応答関数) で, 減 衰記憶の仮定により時間差 $t-t^{\prime}, t-t^{\prime \prime}, \cdots \cdots \cdot$ 単調減少関数にな る. 現時刻 $t$ 亿準拠した時刻 $t^{\prime}\left(-\infty \leqq t^{\prime} \leqq t\right)$ における Cauchy の相対ひずみテンソルを $\boldsymbol{C}\left(t^{\prime}, t\right)$ として, $\boldsymbol{\Gamma}\left(t^{\prime}\right)$ は $\boldsymbol{\Gamma}\left(t^{\prime}\right)=\boldsymbol{C}\left(t^{\prime}\right.$, $t)-1$ となる. しかし, $\boldsymbol{C}\left(t^{\prime}, t\right)$ のかわりに Finger の相対ひず みテンソル $\boldsymbol{C}^{-1}\left(t^{\prime}, t\right)$ を用いても式(14)と全く同じ形の式が得られ るので3)5)34), ここでは

*9遠い過去における変形ほど, 現時刻に抢ける応力に対する寄 与が小さい，という基本的な仮定.

*10 現洔刻における extra stress が，着目した質点近傍の過去の 変形勾配（式(14)でいえば $\boldsymbol{\Gamma}\left(t^{\prime}\right)$ に相当する）の履歴だけによって

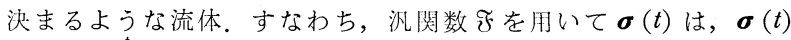

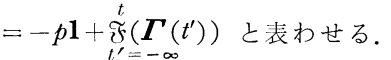




$$
\boldsymbol{\Gamma}\left(t^{\prime}\right)=\boldsymbol{C}^{-1}\left(t^{\prime}, t\right)-\mathbf{1}
$$

とする. 現時刻 $t$ で位置座標 $\boldsymbol{x}=\left(x_{1}, x_{2}, x_{3}\right)$ を占める質点が過去 の時刻 $t^{\prime}$ で位置座標 $\boldsymbol{x}^{\prime}=\left(x_{1}{ }^{\prime}, x_{2}{ }^{\prime} x_{3}{ }^{\prime}\right)$ を占めていたとして, $\boldsymbol{C}^{-1}\left(t^{\prime}, t\right) の i j$ 成分 $G^{-1}{ }_{i j}\left(t^{\prime}, t\right)$ は,

$$
C^{-1}{ }_{i j}\left(t^{\prime}, t\right)=\sum_{k=1}^{3} \frac{\partial x_{i}}{\partial x_{k}^{\prime}} \frac{\partial x_{j}}{\partial x_{k}^{\prime}}
$$

で与えられる. 式(14)の一重積分は $\int_{-\infty}^{t} f\left(t-t^{\prime}\right) g\left(t^{\prime}\right) d t^{\prime}$ の形をして いるが，乙の形の積分はたたみ込み積分と呼ばれ，線形の刺激一 応答理論から得られる普遍的な形である ${ }^{3)}$. また, 式(14)の多重時 間積分を $n$ 重積分 $(n=2,3,4)$ で止めたものを $n$ 次粘弾性理論 という.

非常にゆっくりした，なめらかな変形*11に対し， $\boldsymbol{\Gamma}\left(t^{\prime}\right)$ を測定 時刻 $t$ のまりで Taylor 展開すれば,

$$
\boldsymbol{\Gamma}\left(t^{\prime}\right)=\sum_{n=1} \frac{(-1)^{n+1}\left(t-t^{\prime}\right)^{n}}{n !} \boldsymbol{\kappa}_{n}(t)
$$

となる ${ }^{5) 3435)}$. こてで $\kappa_{1}(t)$ は時刻 $t$ でのひずみ速度を， $\boldsymbol{\kappa}_{n}(t)$ $(n \geqq 2)$ はひずみの加速度を表わし，次式で与えられる。

$$
\boldsymbol{\kappa}_{1}(t)=\boldsymbol{\kappa}(t), \boldsymbol{\kappa}_{n+1}(t)=\frac{\delta \boldsymbol{\kappa}_{n}(t)}{\delta t}
$$

式(17)および(18)を式(14)に代入して積分すれば，応力は次の形で得ら れる

$$
\boldsymbol{\sigma}(t)=-p \mathbf{1}+\sum_{n=1} \boldsymbol{M}_{n}(t)
$$

ここで, $M_{n}(t)$ は $\kappa_{1}(t), \kappa_{2}(t), \cdots \cdots, \kappa_{n}(t)$ の関数であって, 例 えば $\boldsymbol{M}_{1}(t), \boldsymbol{M}_{2}(t)$ は， $\alpha, \beta$ および

$$
\boldsymbol{M}_{1}(t)=\alpha \kappa_{1}(t), \boldsymbol{M}_{2}(t)=\beta \kappa_{1}(t)^{2}+\zeta \kappa_{2}(t)
$$

となる. 式(19)における級数を $n$ 次 $(n=2,3,4)$ までに止めたもの

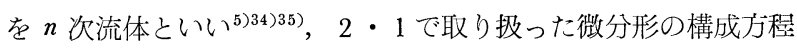
式の一つになる.

多重積分展開形の構成方程式は, 閉じた形の応力-ひずみ関係 が求まらないとと，および核関数が多いため一般に実験による検 証が非常に困難であるとと, などの理由のため現在ではあまり用 いられない

\section{$2 \cdot 3 \cdot 2$ 閉じた形の積分形構成方程式}

分子論的考察をとり入れやすく, 実験による検証が可能である というような主として実用的見地から, 現在最もよく用いられて いるのは, 閉じた形の積分形構成方程式で, 相対ひずみテソルの 時間相関に関して一重積分のものである．ての方程式の一般的な 形は，次のように表わせる3 ${ }^{3) \sim 5}$.

$$
\begin{aligned}
\boldsymbol{\sigma}(t) & =-p \mathbf{1}+\int_{-\infty}^{t}\left\{\mu_{1}\left(t, t^{\prime}\right)\left[\boldsymbol{C}^{-1}\left(t^{\prime}, t\right)-\mathbf{1}\right]\right. \\
& \left.+\mu_{2}\left(t, t^{\prime}\right)\left\{\boldsymbol{C}\left(t^{\prime}, t\right)-\mathbf{1}\right\rceil\right\} d t^{\prime}
\end{aligned}
$$

こてで, $\mu_{1}\left(t, t^{\prime}\right)$ と $\mu_{2}\left(t, t^{\prime}\right)$ は記憶関数（応答関数）であって， 過去の時刻 $t^{\prime}$ 亿おける物体の変形状態 $\left(\boldsymbol{C}^{-1}\right.$ と $\boldsymbol{C}$ で表わされる) が，時刻 $t$ における応カテンソル $\boldsymbol{\sigma}(t)$ に及ぼす寄与の大きさを 与えるものである.

単純せん断流動のとき, 主法線応力差 $\left(\sigma_{11}-\sigma_{22}\right)$ には $\mu_{1}-\mu_{2}$ が, 副法線応力差 $\left(\sigma_{22}-\sigma_{33}\right)$ には $\mu_{2}$ だけが寄与するてとを考慮 して, $\mu_{1}=(1+\varepsilon) \mu, \mu_{2}=\varepsilon \mu$ とおいて, 式(21)在

$$
\begin{aligned}
\boldsymbol{\sigma}(t) & =-p \mathbf{1}+\int_{-\infty}^{t} \mu\left(t, t^{\prime}\right)\left\{(1+\varepsilon)\left[\boldsymbol{C}^{-1}\left(t^{\prime}, t\right)-\mathbf{1}\right]\right. \\
& \left.+\varepsilon\left\{\boldsymbol{C}\left(t^{\prime}, t\right)-\mathbf{1}\right]\right\} d t^{\prime}
\end{aligned}
$$

*11 例えば，遲い定常流，低周波数の正弦振動変帅など．
と表わすととが多い. 式(22)の場合, 単純せん断流動において

$$
\varepsilon=\left(\sigma_{22}-\sigma_{33}\right) /\left(\sigma_{11}-\sigma_{22}\right)
$$

が成立する，単純せん断流動におけるせん断応力 $\sigma_{12}$ と主法線応 力差だけを問題にする場合には，式(21)も(22)も本質的に同じである から，以下ではもっぱら式(22)を用いる。

(1) 一般化 Maxwell 模型（ 3 次元線形粘弾性）

式(22)において， $\mu$ が $\left(t-t^{\prime}\right)$ だけの関数であり， $\varepsilon=0$ とすると， いわゆる 3 次元線形粘弾性の一般化 Maxwell 模型3)936) が得ら れる。

$$
\begin{aligned}
\mu\left(t, t^{\prime}\right) & =\mu\left(t-t^{\prime}\right)=\sum_{i} \frac{G_{i}}{\tau_{i}} \exp \left(-\frac{t-t^{\prime}}{\tau_{i}}\right) \\
& =\int_{-\infty}^{\infty} \frac{H(\tau)}{\tau} \exp \left(-\frac{t-t^{\prime}}{\tau}\right) d \ln \tau
\end{aligned}
$$

こてで $\tau_{i}($ または $\tau)$ および $G_{i}$ (または $\left.H(\tau)\right)$ は, それぞれ線 形の緩和時間および線形の緩和強度（または緩和スペクトル）で ある. この模型は, 定常せん断流動に対し, せん断速度 $\kappa$ に比 例するせん断灾力と, $\kappa^{2}$ に比例する主法線応力差とを与える.

(2) 一時間一重積分形の非線形構成方程式

一時間一重積分形の非線形構成方程式は，式(24)における $G_{i}$ ま たは $H(\tau)$ がひずみ速度テンソルの不変量あるいは相対ひずみテ ンソルの不変量に依存すると仮定したものであり，前者をひずみ 速度依存形 ( $\mathrm{R}$ モデル), 後者を相対ひずみ依存形 ( $\mathrm{S}$ モデル) と 呼ぶ336) 8). 例をあげれば，次のようになる。

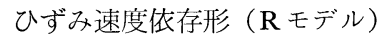

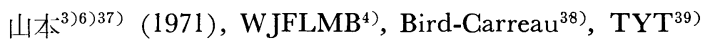

相対ひずみ依存形 ( $\mathrm{S}$ モデル)

山本 ${ }^{3) 6)}(1972), \mathrm{BKZ}^{40) * 12}, \mathrm{BKZ}$ の特別な形*12 $\left(\mathrm{Zapas}^{41)}\right.$, Bogue-Doughty ${ }^{42)}$, Doughty-Bogue ${ }^{19)}$, Adams-Bogue ${ }^{43)}$, Zapas-Phillips ${ }^{44)}$, Chen-Bogue $\left.{ }^{45}\right)$

これらのモデルの記憶関数の形は, テンソル $\boldsymbol{A}\left(t^{\prime}\right)$ の 3 つの不 変量をまとめて $J_{A}\left(t^{\prime}\right)$ で表わすととにすれば，一般的に次式で - 表わせる ${ }^{3) 6) 8) 37) . ~}$

$$
\begin{aligned}
\mu\left(t, t^{\prime}\right) & =\sum_{i} \frac{G_{i} f_{i}\left(J_{A}\left(t^{\prime}\right)\right)}{\tau_{i}} \exp \left(-\frac{t-t^{\prime}}{\tau_{i}}\right) \\
& =\int_{-\infty}^{\infty} \frac{H\left(\tau, J_{A}\left(t^{\prime}\right)\right)}{\tau} \exp \left(-\frac{t-t^{\prime}}{\tau}\right) d \ln \tau \quad \text { (25) }
\end{aligned}
$$

$J_{A}\left(t^{\prime}\right)$ として，ひずみ速度テンソルの不変量 $J_{R}\left(t^{\prime}\right)$ をとったも

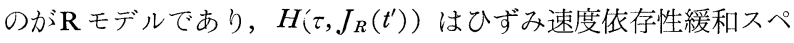
クトルである。 また $J_{A}\left(t^{\prime}\right)$ として， $\left(t, t^{\prime}\right)$ 間の相対ひずみテン ソルの不変量 $J_{S}\left(t, t^{\prime}\right)$ をとったものが $\mathrm{S}$ モデルであり， $H\left(\tau, J_{S}\right.$ $\left.\left(t, t^{\prime}\right)\right)$ は相対ひずみ依存性緩和スペクトルである。式(25)から明 らかなように，乙れらのモデルにおける緩和時間は線形であり， 緩和強度だけがひずみ，あるいはひずみ速度に依存すると仮定さ れる。ただし， $\tau$ をdummy 量のように考光れば，緩和時間が非 線形のモデル（例えば式(28)参照）の場合も，形式的には式(25)のよ うに書けるととがあるので，ての線形性の問題には十分注意する 必要がある。

\section{（3）二時間一重積分形の非線形構成方程式}

二時間一重積分形の非線形構成方程式は, 緩和強度だけでなく, 緩和時間も応力, ひずみ, あるいはひずみ速度に依存すると仮定 したものであって，次のように分類するととができる゙78).

*12 これらのモデルでは, 式(22)ではなく式(21)の形の構成方程式を 取报っている. 
ひずみ速度依存形 (RR モデル)

山本 $^{7}(1973)$ 高橋一升田一小野木 ${ }^{8)}$, David ${ }^{46)}$, Carreau ${ }^{47)}$, Meister ${ }^{48}$

混合形 (SR モデル，RS モデル)

高橋一升田一小野木 ${ }^{8)}$ ，中村一吉岡一木村 ${ }^{49}$

相対びずみ依存形 (SS モデル)

山本 ${ }^{7)}(1973)$, 高橋一升田一小野木 ${ }^{8)}$

応力依存形 (StSt モデル)

高橋一升田一小野木 ${ }^{50)}$ ， Kaye ${ }^{51)}$, Marrucci-TitomanlioSarti ${ }^{52)}$

てれらのモデルの記憶関数の形は, 一般的に次式で表わされる ${ }^{778)}$.

$$
\begin{aligned}
\mu\left(t, t^{\prime}\right) & =\sum_{i} \frac{G_{i} f_{i}\left(J_{A}\left(t^{\prime}\right)\right)}{\tau_{i}} \exp \left[-\int_{t^{\prime}}^{t} \frac{d t^{\prime \prime}}{\tau_{i} g_{i}\left(J_{B}\left(t^{\prime \prime}\right)\right)}\right] \\
& =\int M\left(\xi, J_{A}\left(t^{\prime}\right)\right) \exp \left[-\int_{t^{\prime}}^{t} \beta\left(\xi, J_{B}\left(t^{\prime \prime}\right)\right) d t^{\prime \prime}\right] d \xi
\end{aligned}
$$

こてでミは緩和時間分布を特徽づけるためのバラメーターで，緩 和係数 $\beta$ は緩和時閒の逆数という意味をもつ. $J_{A}$ および $J_{B}$ と してそれぞれ $J_{S}, J_{R}$ をとるものを $\mathrm{SR}$ モデルと名づけ，他のモ デルの㭔び方についても同様に定める。例えば SS モデルでは $J_{A}\left(t^{\prime}\right)=J_{S}\left(t, t^{\prime}\right), J_{B}\left(t^{\prime \prime}\right)=J_{S}\left(t^{\prime \prime}, t^{\prime}\right)$ となる。乙れらのモデルでは， 緩和時閒分布を離散スペクトルで表わすとき，テンソル不変量に 依存する緩和時間と緩和強度がそれぞれ $\tau_{i} g_{i}$ と $G_{i} f_{i} g_{i}$ で表わさ れる。乙のような二時間 $\left(t^{\prime}, t^{\prime \prime}\right)$ 一重積分形の構成方程式は，た いていが Lodge, 山本らの分子網目理論953 〜 55)にその基檚をおい ているが，Meister ${ }^{48)}$ はからみ合い点の生成に関連する緩和侍減 とその消滅に関連する緩和時閒とを区別するときは，三時閒 $\left(t^{\prime}\right.$, $\left.t^{\prime \prime}, t^{\prime \prime \prime}\right)$ が必要であるとしている。

（4）その他の一重積分形の非線形構成方程式

Bogue と White ${ }^{5) 4556)}$ は，緩和時間がひずみ速度テンソルの 不変量の $t^{\prime}$ と $t$ の間の平均に依存すると仮定して, 次の形をもつ 記憶関数を提案した。

$$
\begin{aligned}
\mu\left(t, t^{\prime}\right) & =\sum_{i} \frac{G_{i}}{\tau_{i}{ }^{*}} \exp \left(-\frac{t-t^{\prime}}{\tau_{i}^{*}}\right) \\
= & \int_{-\infty}^{\ln ^{*} \tau_{m}}{ }^{*} \frac{H\left(\frac{\tau^{*}}{1-a<J_{R}^{1 / 2}>\tau^{*}}\right)}{\tau^{*}\left(1-a<J_{R}^{1 / 2}>\tau^{*}\right)} \exp \left(-\frac{t-t^{\prime}}{\tau^{*}}\right) d \ln \tau^{*}
\end{aligned}
$$

(28)

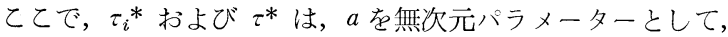

$$
\tau_{i}^{*}=\frac{\tau_{i}}{1+a<J_{R}^{1 / 2}>\tau_{i}}, \tau^{*}=\frac{\tau}{1+a<J_{R}^{1 / 2}>\tau}
$$

で与えられる。ただし，

$$
<J_{R}^{1 / 2}>=\frac{1}{t-t^{\prime}} \int_{t^{\prime}}^{t}\left|J_{R}\left(t^{\prime \prime}\right)\right|^{1 / 2} d t^{\prime \prime}
$$

である．乙のモデルは，BKZ の特別な形と同程度に，定常せん 断流動 ${ }^{19) 45) ， お よ ひ ゙ ス ト レ ス ・ オ ー ハ ゙ ー シ ュ ー ト ~}{ }^{45)}$ の実験結果と 一致し，特に主法線応力差のストレス・オーバーシュートに関し ては BKZ の特別な形よりもよく実験結果と一致するととが知 られている ${ }^{45)}$ 。さらにてのモデルは，伸長流動（1 軸伸長流動 ${ }^{21)}$ ${ }^{57)}$ ，二軸伸長流動 ${ }^{23)}$ ) の実験結果ともかなりよく一致する。しか し，乙のモデルを実験結果と定量的に一致させるためには，せん 断応力と主法線応力差とでそれぞれ異なった $a$ の值を用いなけれ ばならないという大きな欠点がある。

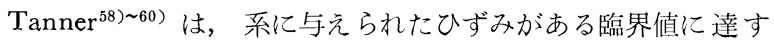

るとからみ命い網目が部分的に破壊すると仮定して，網目破塤模 型（network rupture model）を提出した。彼は，式(22)における 記憶関数 $\mu$ を線形（式(24)）とし， $t^{\prime}$ についての時間積分の下限 $-\infty$ を $t-\tau_{R}$ に置き換えた。こてで $\tau_{R}$ はからみ合い網目の寿 命に相当し，

$$
\begin{gathered}
\operatorname{Tr}\left[\boldsymbol{C}^{-1}\left(t_{R}{ }^{\prime}, t\right)-1\right]=B^{2} \quad(B=1 \sim 10) \\
\tau_{R}=t-t_{R}{ }^{\prime}
\end{gathered}
$$

の条件から決まる。このモデルは，高分子濃厚系が示す種々の非 線形粘弾性現象を定性的にはよく表わすが ${ }^{58) ~ 60) ， ~ ス ト レ ス ・ 才 ~}$ 一バーシュートの実験結果を満足に説明するためには，網目の破 壊ひずみに分布をもたせて一般化するととが必要であると考えら れる ${ }^{59)}$.

Lianis $~^{{ }^{61) ~ 63)}}$ は，大変形非線形の弾性論 ${ }^{3)}$ を粘弹性体一拡張 したとみられる構成方程式二つを提出した。これらの方程式は， スチレンーブタジエンゴム (SBR) を用いたかなり複雑な変形様 式（ただし変形量は小さい）の実験結果と非常によく一致するこ

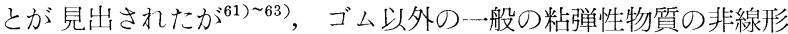
粘弾性現象を記述することはできない。

\section{3．高分子濃厚系の非線形粘弾性現象}

2で取り扱った種々の構成方程式のうち，最も有用であると思 われる閉じた形の一重積分形の構成方程式つ，非線形粘弾性現象 に対する適用性を以下で検討する。一重積分形の構成方程式のう ち，種々の変形様式に対する実験結果との一致が最もよいと期待 されるのは， $2 \cdot 3 \cdot 2 の(2)$ と(3)で述べた一時間形および二時間形 のモデルである。式(25)の一時間形のモデルは，式(26)または式(27)の 二時間形のモデルにおいて $g_{i}=1$ または $\beta\left(\xi, J_{B}\left(t^{\prime \prime}\right)\right)=\beta(\xi)$ の特 別の場合であると考光られることから，以下では二時間形のモデ ルの結果を中心として述べる。さらに二時間形のモデルのうちの 混合形 (SR と RS) の与える結果は，それぞれ RR および SS の与える結果と類似しており，乙れらの混合形モデルが特によく 実験結果を説明できるというととではないてとがわかっているの で8)，以下ではRR（ひずみ速度依存形），SS（相対ひずみ依存形） および StSt（応力依存形）の三つのモデルから得られる結果を中 心に述べるととにる。それらの結果を導くにあたっては，分子 網目理論に基づく物理的考察により， $f_{i}$ と $g_{i}$ は，テンソル不変 量（応力，ひずみ，ひずみ速度のうちのどれか）の減少関数であ ると考えた．なお，テンソル不変量としては，次のものを採用す る。すなわち，応力テンソル $\boldsymbol{\sigma}$ および相対ひずみテンソル $\boldsymbol{C}^{-1}$ $\left(t^{\prime}, t\right)$ の不変量については, $\operatorname{det} \boldsymbol{A}$ をテンソル $\boldsymbol{A}$ の行列式として,

$$
\begin{aligned}
J_{A}= & \left\{I_{A}, I I_{A}, I I I_{A}\right\},\left(A=\boldsymbol{\sigma} \text { or } \boldsymbol{C}^{-1}\right) \\
& I_{A}=\operatorname{Tr} \boldsymbol{A} \\
& I I_{A}=(1 / 2)\left[I_{A}{ }^{2}-\operatorname{Tr}(\boldsymbol{A} \cdot \boldsymbol{A})\right] \\
& I I_{A}=\operatorname{det} \boldsymbol{A}
\end{aligned}
$$

とし，ひずみ速度テンソル $\boldsymbol{\kappa}$ の不変量については， $I_{\kappa}$ と $I I I_{\kappa}$ が 上式と同じとし，II

$$
I I_{\kappa}=\operatorname{Tr}(\boldsymbol{\kappa} \cdot \boldsymbol{\kappa})
$$

と定義する*13

以下で取り扱う非線形粘弾性現象は，次の 12 種である。(1)定常 せん断流動，(2)ストレス・オーバーシュート，(3)断続流動（inter*13 $I I_{\kappa}$ を式(32)とすると負になってしまうので，便宜上式(33)を採 用する。 
rupted flow)，(4)定常せん断流動停止後の応力緩和，(5)大変形下 の応力緩和，(6) 2 段応力緩和，(7)定常せん断流動之微小正弦振動 変形の重畳 (平行および直交重ね合わせ)，(8)大振幅の正弦振動， (9)定常せん断流動に伴う回復性ひずみ，(10)応力成長に伴う回復性 ひずみ，(11)定常せん断流動停止後の応力緩和中の回復性ひずみ, (12)一軸伸長流動。乙のうち，(12)以外はすべてせん断流動である。 また最近，せん断で行われた様々の測定様式を一軸伸長に応用し ようという試みがなされつつあり ${ }^{64)}$ ，さらにねじり（せん断）之 伸長を同時に与えるという試み ${ }^{63) 65)}$ も行なわれている。12種の現 象のうち今回は(1)〜(3)までを取り上げ，次回（総説〔II〕）で(4)〜 (12)を取り上げることとする。

ストレス・オーバーシュート, 定常せん断流動停止後の忘力緩 和などの非定常非線形粘弾性の実験は非常にむつかしく ${ }^{66)}$, 永沢 $ら^{67) 68)}$, Meissner ${ }^{69)}$, Huppler $ら^{70)}$, 藤木ら ${ }^{71}$ によって指摘され た諸点に注意しない限り，その実験結果は全く信用できないもの となってしまう ${ }^{66)}$. 円錐一-円板形のワイセンベルグ・レオゴニオ メーターを用いて実験を行なう場合の主な注意点は, 次の五つに まとめられる ${ }^{66)}$.

（1）充分強いバネを使用するとと.

（2）円錐は小さい半径のもので，円錐一円板間のギャップの角 度の比較的大きいものを使用すること.

(3) ギャップの間隔を常に正しく保つとと.

（4）慣性の効果と試料の粘度の効果がともに無視できるととを 確かめること. 非定常非線形粘弾性の実験を行なうとき, 粘度の 効果を見積る方法やその補正法には今のとてろ定まった方法がな いが, 振動法線応力に対してなされた粘度の効果の補.正法 ${ }^{72)}$ は重 要であり，大いに参考にならう。

（5）試料としては，長時間静置して履歴をもたないものを用い るとと.

\section{$3 \cdot 1$ 定常せん断流動}

$\sigma_{s}, \sigma_{n}, \kappa, \eta(\kappa)$ および $\theta(\kappa)$ をそれぞれせん断応力, 主法線応 力差, せん断速度*14, 粘度および主法線応力差係数とし, $\lambda$ を時 間差 $\left(=t-t^{\prime}\right)$ とする. 式(22)から出発すれば，一般的に次式を得 る. $\left(f_{i}\right.$ と $g_{i}$ の具体的な形を指定しなければ, 式(26)と式(27)から 得られる結論は全く同じであるから，式(25)との対応がつきやすく， 後で示すようにいろいろと取扱いが便利という意味で，以下記憶 関数としては式(26)を採用するてととする.)

$$
\begin{gathered}
\sigma_{s} \equiv \sigma_{12}=\kappa \eta(\kappa)=\kappa \sum_{i} \eta_{i}(\kappa)=\kappa \sum_{i} \int_{0}^{\infty} z_{i} \lambda d \lambda \\
\sigma_{n} \equiv \sigma_{11}-\sigma_{22}=\kappa^{2} \theta(\kappa)=\kappa^{2} \sum_{i} \theta_{i}(\kappa)=\kappa^{2} \sum_{i} \int_{0}^{\infty} z_{i} \lambda^{2} d \lambda
\end{gathered}
$$

いずれのモデルの場合も， $z_{i}$ は入に関しては指数関数的な減少関 数であり， $\lambda$ を固定すれば $\kappa$ の減少関数である.すなわち， $\eta(\kappa)$ と $\theta(\kappa)$ は $\kappa$ の減少関数となる.

$\eta(\kappa)$ が指数則領域で $\kappa$ の何乗に比例するかとか, 式

$$
J_{e}(\kappa)=\frac{\sigma_{n}}{2 \sigma_{s}{ }^{2}}=\frac{\theta(\kappa)}{2 \eta(\kappa)^{2}}
$$

で定義される定常せん断コンプライアンス $J_{e}(\kappa)$ が $\kappa$ の増加関数 になるか減少関数になるかといった問題は， $f_{i}$ と $g_{i}$ の具体的な

*14 女九断速度 $\kappa$ は $\kappa=\sqrt{(1 / 2) I I_{\kappa}}$ で定義される。すすおち, 流れの方向を 1 , 速度勾配の方向を 2 として, $\kappa=\partial v_{1}\left(x_{2}, t\right) / \partial x_{2}$ である。
形に依存する，実験的には，分子量分布の非常に狭い高分子の濃 厚系では $\eta(\kappa)$ が $\kappa$ の約一 0.8 乗に比例し ${ }^{73) ~ 75)}, J_{e}(\kappa)$ が $\kappa$ の増

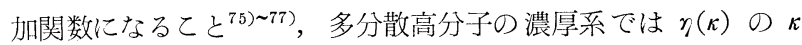
依存性はそれよりも小さく ${ }^{74775)}, J_{e}(\kappa)$ が $\kappa$ の減少関数になるて と ${ }^{75) 77}$ が見出されている。 また単分散高分子の濃厚系における $J_{e}(\kappa)$ の (濃度) および $M$ (分子量) 依存性について, $\kappa \rightarrow 0$ で $M^{0} / c^{2}$ に比例し， $\kappa$ が增加してからみ合い点の密度が減少すると 共に Rouse 理論で予言されるような $c, M$ 依存性 $(M / c$ に比例 する）に漸近することが知られている ${ }^{76)}$. さらに，高分子電解質 を用いた実験によって， $J_{e}(\kappa)$ がからみ合い点の密度の減少ばか りでなく, 分子鎖コイルの大きさの変化（添加塩の濃度の違いに よる分子鎖コイルの大きさの変化および $\kappa$ の増加に伴う分子鎖 コイルの伸長）にも大きく影響されることが見出されている 非ニュートン粘性の分子論としては，よく知られた Graessley $\left.{ }^{79}\right)^{800}$ の理論がある。乙の理論では, 単分散高分子の粘度が指数則 領域で $\eta(\kappa) \propto \kappa^{-0.82}$ となり ${ }^{80)}$ ，また $\tau_{0}$ を時定数として $\eta(\kappa) / \eta_{0}$ が $\kappa \tau_{0}$ の普遍関数となるが $\left.{ }^{79} 80\right)$, 後者の結果も分子量分布の㹨い 高分子濃厚系の実験結果 ${ }^{7377476) 77) 81)}$ 飞一致する。実験的に得られ た $\tau_{0}$ が分子量 $M$ の 乗 $(a \fallingdotseq 3.5)$ に比例する ${ }^{74) 76) 77) 81)}$ ととか ら， $\tau_{0}$ は線形の最長緩和時間 $\tau_{m}$ に相当するものと考えられてき た 。しかし，でく最近尾崎ら $\left.{ }^{82}\right)$ にって， $c M \geqq 10^{6}(c$ は $g / c c$ で表わした高分子の濃度）のポリスチレン濃厚系で， $\tau_{m}$ および $\eta_{0}$ が $M^{3.5}$ に比例するにもかかわらず， $\tau_{0}$ はそれと全く異なる $M$ 依存性をもつととが実験的に見出されている.

小野木，志賀らの㬰験によれば，分子量の異なる単分散高分子 の二成分混合物に対しては, Graessley の理論と実験結果は一致 せず，乙の理論の多分散高分子への拡張には問題があると思われ る

次に，副法線応力差 $\left(\sigma_{22}-\sigma_{33}\right)$ について述べる．その大きさ と符号について今まで様々の実験結果が得られてきたが，最近の 厳密な実験的検討に上れば，定常単純せん断流動における $\left(\sigma_{22}-\right.$ $\sigma_{33}$ ) は負（压縮力）で， その絶対值は主法線応力差 $\left(\sigma_{11}-\sigma_{22}\right)$ $(>0$, 張力) に比べ1オーダーほど小さいという結果が得られ ている ${ }^{84) \sim 87)}$.

\section{$3 \cdot 2$ ストレス・オーバーシュート}

時刻 $t=0$ において，瞬間的に $\kappa$ 一定のせん断流動を開始する. $\kappa$ が大きいとき，応力は Fig. 1 亿示すようにオーバーシュートす るが, せん断応力 $\sigma_{s}$ と主法線応力差 $\sigma_{n}$ とが極大になる時間を それぞれ $t_{m}{ }^{s}, t_{m}{ }^{n}$ とする, さらに, 成長粘性率 $\tilde{\eta}(t, \kappa)$, 成長主法 線応力差係数 $\tilde{\theta}(t, \kappa)$ を次式で定義する.

$$
\sigma_{s}(t)=\kappa \tilde{\eta}(t, \kappa)=\kappa \sum_{i} \tilde{r}_{i}(t, \kappa)
$$

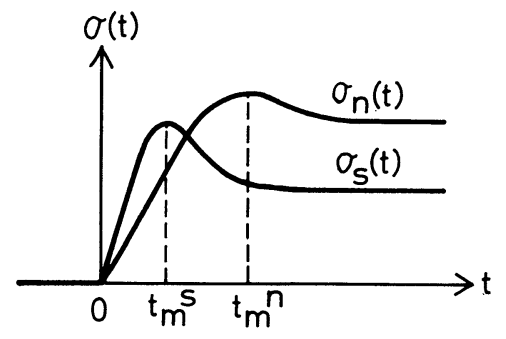

Fig. 1. A schematic representation of the stress overshoot of the shear stress $\sigma_{s}(t)$ and the first normal stress difference $\sigma_{n}(t)$. 


$$
\sigma_{n}(t)=\kappa^{2} \tilde{\theta}(t, \kappa)=\kappa^{2} \sum_{i} \tilde{\theta}_{i}(t, \kappa)
$$

応力の時間微分は, StSt 以外のモデルでは次式で与兄られる。

$$
\begin{gathered}
\frac{d \sigma_{s}(t)}{d t}=\kappa \sum_{i} \tau_{i} z_{i}{ }^{*} a_{i} \\
\frac{d \sigma_{n}(t)}{d t}=\kappa^{2} t \sum_{i} \tau_{i} z_{i}^{*} \cdot\left(a_{i}+1\right)
\end{gathered}
$$

$z_{i}^{*}$ は, 時間 $t$ の指数関数的な減少関数で, $0 \leqq t<\infty$ において常

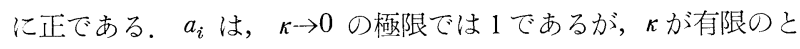
きは時間 $t$ の単調減少関数で, $\kappa$ が大きいときにはある有限の時 間 $t$ で正から負に変化する。すなわち，応力の時間微分がゼロに なって，応力は極大值をもつととがわかる．また， $a_{i}$ が $t$ の単調 減少関数であるととから, 式(39)および(40)において単一項をとる限 り応力の時間微分が有限の $t$ の間に 2 回ゼロになるととはなく, $\mathrm{RR}, \mathrm{SS}$ モデルなどでは, 応力は定常值に達する前にアンダーシ ュートしないととになるが，複数項をとる場合はわからない，分 子量が大きく異なる単分散高分子の二成分混合物の場合には，二 つの極大，従ってその間にアンダーシュートが生じる可能性を示 すことができる50).

StSt モデルに対する応力微分の式は省略するが，それぞれ式 (39)および(40)の右辺に相当する項にさらにもう1 項が加わる。 この モデルの場合には，極大值付近の大きな応力がからみ合い点の消 滅に大きく影響すれば，オーバーシュートのあとにアンダーシュ 一トが起てる可能性もある ${ }^{47) 50)}$. 現在までに行なわれた実験の中 には，反が大きいときアンダーシュートが現われているものも多 いが，最近の注意深い測定ではアンダーシュートは観測されてい ない67)88889).

最近，van Es とChristensen ${ }^{90)}$ は，次式で定義される生長関 数 $\tilde{\Theta}(t, \kappa)$ が $\tilde{\theta}(t, \kappa)$ と同様に極大をもつとともに, $\kappa$ 依存性を もつことを実験的に見出している.

$$
\tilde{\theta}(t, \kappa)=-t \tilde{\eta}(t, \kappa)+\int_{0}^{t} \tilde{\eta}(\lambda, \kappa) d \lambda+\tilde{\theta}(t, \kappa)
$$

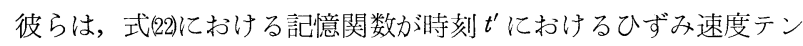
ソルの不変量だけに依存するときは，その形がどうであれ， $\tilde{\theta}(t$, $\kappa)$ が $た$ 単調增加関数であると同時に $\kappa$ 依存性をもたないととに なって，実験結果と矛盾するととを示した ${ }^{90)}$.

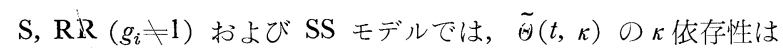
説明でき乃が，極大をもつととは説明できない。なぜなら， $\tilde{\Theta}(t$, ๘) の時間微分が

$$
\frac{\partial \tilde{\hat{s}}(t, \kappa)}{\partial t}=\frac{\partial \tilde{\theta}(t, \kappa)}{\partial t}-t \frac{\partial \tilde{\eta}(t, \kappa)}{\partial t}=t \sum_{i} \tau_{i} z_{i}^{*}>0 \quad(0<t<\infty)
$$

となって， Rモデル $\left(g_{i}=1\right)$ と同じく $\tilde{\Theta}(t, \kappa)$ が $t$ の単調増加

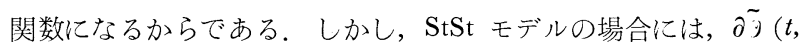

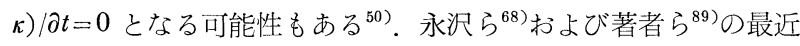
の実験結果によれば， $\tilde{\theta}(t, \kappa)$ の極大がかなり顕著なときでも， $\tilde{\Theta}(t, \kappa)$ には極大が現われにくかった.

式(39)および(40)において，せん断応力の時間微分には $a_{i}$ が，主 法線応力差のそれには $a_{i}+1$ が現われることから，同一の $\kappa$ にお いて，緩和時間の分布によらず,

$$
t_{m}{ }^{n}>t_{m}{ }^{s}
$$

が成立するととがわかり，StSt モデルの場合にも同様な理由でと の関係式が成立する ${ }^{50)}$. 主法線応力差の極大時間の方が，せん断 応力の極大時間より長いというとの結論は, 実験事実 ${ }^{45567) 69 / 70) 899}$
91) 93) としてょく知られている。

$\mathrm{RR}$ および $\mathrm{SS}$ モデルでは， $a_{i}$ の形から $t_{m}{ }^{s}, t_{m}{ }^{n}$ が $\kappa$ の減少 関数であるてとがわかる. 特に SS モデルで $g_{i}=1$ とし（ $\mathrm{S}$ モデ ルになる), さらに $f_{i}=f$ とすれば*15, $a, b$ を定数 $(a<b)$ として

$$
t_{m}{ }^{s}=\frac{a}{\kappa}, \quad t_{m}{ }^{n}=\frac{b}{\kappa}
$$

となるととがわかる ${ }^{50)}$.また $g_{i} \div 1$ の場合には，

$t_{m}{ }^{s}, t_{m}{ }^{n}$ は $\kappa$ の減少関数で, $\kappa$ 依存性は $\kappa^{-1}$ より弱い (45) ことがわかる ${ }^{50)}$. 実験的には， $\kappa$ があまり大きくないとき， $\kappa t_{m}^{s}$

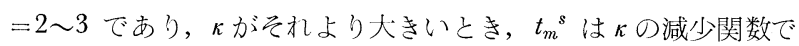

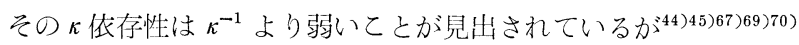
88)89)91 99), 乙の結果は, $\kappa$ の小さいところでは $\mathrm{S}$ モデル $\left(g_{i}=1\right)$, $\kappa$ が大きいところでは SS モデル $\left(g_{i} \doteqdot 1\right)$ を採用すればよく説明 される ${ }^{50)}$.

$\gamma$ をせん断ひずみとして， $\mathrm{S}$ モデルにおける $f_{i}(\gamma)$ の形を次式 とする.

$$
f_{i}(\gamma)=f(\gamma)=\frac{1}{\left(1+A \gamma^{l}\right)^{k}}
$$

ここで, $A, k, l$ は正の無次元パラメーターである. このとき, $t_{m}{ }^{s}, t_{m}{ }^{n}$ は

$$
t_{m}{ }^{s}=\frac{1}{\kappa} \sqrt[\iota]{\frac{1}{A(k l-1)}}, \quad t_{m}^{n}=\frac{1}{\kappa} \cdot \sqrt{\frac{2}{A(k l-2)}} \text { (47) }
$$

となる ${ }^{7)}$. 従って $k l>2$ でないと両灾力のオーバーシュートが説 明できないととになるが，大変形下の応力緩和の実験結果 ${ }^{100) 101)}$ からは， $1<k l<2$ が得られており，乙のときは主法線応力差の オーバーシュートが説明できない．

単一の緩和時間をもつ単一緩和現象と近似す机ば， RR モデル

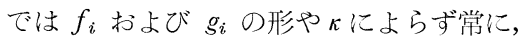

$$
\frac{t_{m}{ }^{n}}{t_{m}{ }^{s}}=2
$$

となる. 一方 $\mathrm{SS}$ モデルでは, $g_{i}=1$ でかつ $f_{i}=\exp (-A \gamma)$ とい うような特別の場合にだけ，乙の関係が成立する。式(48)汢，分子 量分布の非常に狭い高分子を用いた最近の実験結果 ${ }^{67) 89)}$ とよく一 致する.

ごく最近, 尾崎ら ${ }^{102) 103)}$ は分子量が非常に高く, 分子量分布が 非常に狭いポリスチレンの濃厚溶液で実験し， $c M \geqq 10^{6}$ の系にお いては $c M<10^{6}$ の系と全く異なって，せん断応力のストレス・ オーバーシュートが現われにくいととを見出した， RR モデルで 単一緩和近似をすると， $\tau_{m}$ を線形の最長緩和時間として， $\sigma_{s}(t) /$ $\sigma_{s}(\infty)$ が $t / \tau_{m}$ と $\kappa \tau_{m}$ だけの関数になって, ての実験結果を説 明できない，緩和時間の分布を考慮し， $\tau_{m}$ が大きいとき $\tau_{i} / \tau_{m}(i$ $=m, m-1, m-2, \cdots \cdots)$ が大きく変化する, すなわち線形の緩和 スペクトル $H(\tau)$ の形が大きく変化すると考杂れば説明できる可 能性もあるが ${ }^{50)}, H(\tau)$ を $\tau / \tau_{m}$ に対してプロットした形が $c M$ $<10^{6}$ の系と全く変わらな( $\left.{ }^{82}{ }^{803}\right)$ ととから，乙の説明も不適当で ある ${ }^{50)}$

尾崎ら ${ }^{102) 103)}$ は, $\mathrm{S}$ モデルにおいて $f_{i}(\gamma)$ の形を

*15 $\mu\left(t-t^{\prime}\right)$ を線形の記憶関数として, $\mu\left(t, t^{\prime}\right)=f\left(J_{S}\left(t, t^{\prime}\right)\right) \cdot \mu$ $\left(t-t^{\prime}\right)$ あるいは $H\left(\tau, J_{S}\left(t, t^{\prime}\right)\right)=f\left(J_{S}\left(t, t^{\prime}\right)\right) \cdot H(\tau)$ と仮定する ととになる。つまり緩和時間はひずみによって変化せず, 緩和強 度がすべての緩和機構で一様に, ひずみの增加とともに隇少する と仮定する。単純せん断流動では，Zapas, Bogue らの特殊 BKZ モデル ${ }^{19) 42) ~}{ }^{45)}$ と同じになる. 


$$
f_{i}(\gamma)=\sum_{j} a_{i j} \exp \left(-b_{i j} \gamma\right)
$$

とするとき，長い緩和時間に対応する $f_{i}(\gamma)$ は分子量が高くなる ほど多くの項数を必要とし，上述の実験結果をよく説明できるこ とを示している．ただし， $a_{i j}$ と $b_{i j}$ は無次元パラメーターであ る、彼らは，ひずみやひずみ速度があまり大きくないとき， $\mathrm{S}$ モ デルで $\eta(\kappa), \tilde{\eta}(t, \kappa)$ さらに次回に述べる緩和粘性率 $\eta(t, \kappa)$ およ びひずみ依存性緩和弾性率 $G(t, \gamma)$ の実験結果が，分子量の低い 場合も高い場合も定量的によく再現されることを示している ${ }^{102)}$ 103).

高分子濃厚系の非定常応答時における系の構造変化について， 様々の議論がなされている. せん断応力のストレス・オーバーシ ュートを例にとれば，それらは大体次の三つに大別できる。乙こ ではその詳細については触れない.

(1) 仮説的な弾性流体と, その有効構造密度の減少によって顶 明しようとするもの (山本 ${ }^{3)}$ Carreau $^{47}$ ) .

（2）チキソトロピー的（可逆的）な構造の破壊と回復との類似 によって説明しようとするもの (Trapeznikov ${ }^{93)}$, Vinogradov ら 94) Malkin $ら^{104)}$ ).

（3）反応速度論的アプローチ：チキソトロピーと弾性の組合わ せで説明しようとするもの (Brodkey ら ${ }^{105)}$ ).

からみ合い網目構造の破壊に必要なエネルギー $E_{s t r}$ について

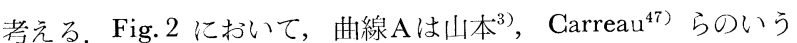

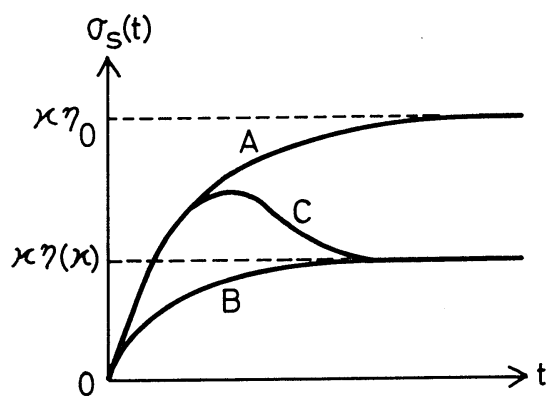

Fig. 2. A schematic representation of the shear stress development in a real fluid (C) and hypothetical fluids ( $\mathrm{A}$ and $\mathrm{B}$ ).

仮説的弾性流体の応力成長曲線を示し， $\kappa=0$ での網目構造が破 壊されずに応力成長が起てる場合に相当する。曲線 $\mathrm{B}$ は最初から $\kappa=\kappa$ でのからみ合い状態になっていて，それ以上構造の破壊も また回復も起てらず，応力成長が起てる場合を示す，実際の高分 子濃厚系では， $t<0$ における静止状態での構造が破壊されない間 は曲線A 一一致し, 破壤が起てると応力はそれより小さくなって 曲線 $C$ のように変化すると考光られる，曲線 $A, \mathrm{~B}$ および $\mathrm{C}$ をそ れぞれ $\sigma_{s}^{(A)}(t), \sigma_{s}^{(B)}(t)$ および $\sigma_{s}(t)$ とし， $t_{s}$ をそれらが定常 状態に達するまでの時間とすれば，曲線 $\mathrm{C}$ に対しその時間までに 供給した総外部仕事 $W$ は次式で与えられる。

$$
W=\int_{\gamma_{0}}^{\gamma_{s}} \sigma_{s}(\gamma) d \gamma=\int_{0}^{t_{s}} \sigma_{s}(t) \frac{d \gamma}{d t} d t=\kappa \int_{0}^{t_{s}} \sigma_{s}(t) d t
$$

この外部仕事は，粘性的な摩擦によって散冕したェネルギー $E_{f}$ と, 弾性エネルギーとして貯蔵されたエネルギー $E_{e l}$ と, 構造の 破壊に使われた仕事 $E_{s t r}$ に分けられるであろう ${ }^{104)}$.

$$
W=E_{f}+E_{e l}+E_{s t r}
$$

$\kappa \sigma_{s}{ }^{(B)}(t)$ を㭙間 $t_{s}$ まで積分したものは， $\kappa=\kappa$ での構造が $t=0$ から $t=t_{s}$ まで保持されたときに供給されるような，仮想的な外 部仕事 $W^{(B)}$ である.

$$
W^{(B)}=\kappa \int_{0}^{t_{s}} \sigma_{s}^{(B)}(t) d t
$$

$W^{(B)}$ は次のように分けられるであろう。

$$
W^{(B)}=E_{f}^{\prime}+E_{e l}^{\prime}
$$

もし $E_{f}+E_{e l}=E_{f}{ }^{\prime}+E_{e l}{ }^{\prime}$ であれば， $E_{s t r}$ は $E_{s t r}=W-W^{(B)}$ ，すな わち Fig. 2 の曲線 $\mathrm{C}$ と曲線 $\mathrm{B} て ゙$ 囲まれた閉曲線の面積に $\kappa$ をか けて求まるはずである，梶浦ら ${ }^{106)}$ はこのような考え方で $E_{s t r}$ を 求めている. しかし, 曲線 $\mathrm{B}$ は $\kappa=\kappa$ の構造のままであり, 曲線 $\mathrm{C}$ は $\kappa=0$ の構造が $\kappa=\kappa$ の構造へと変化することを考えれば, $E_{f}+E_{e l}=E_{f}{ }^{\prime}+E_{e l}{ }^{\prime}$ とは考光られない50). なお， RR モデルの場 合 $\sigma_{s}^{(B)}(t)$. が式

$$
\sigma_{s}^{(B)}(t)=\kappa \sum_{i} G_{i}(\kappa) \tau_{i}(\kappa)\left\{1-\exp \left(-t / \tau_{i}(\kappa)\right)\right\}
$$

で表わせることより，

$W$ - $W^{(B)}$ は次のようになる ${ }^{50)}$.

$$
W-W^{(B)} \leqq \frac{\kappa^{2}}{2}[\theta(0)-\theta(\kappa)]
$$

ただし，式(54)の $G_{i}(\kappa)$ および $\tau_{i}(\kappa)$ は，それぞれ $G_{i} f_{i}(\kappa) g_{i}(\kappa)$ および $\tau_{i} g_{i}(\kappa)$ であり，式(55)等号は $g_{i}=1$ のときである.

Malkin, Vinogradov, Trapeznikov 弓 $^{93996) 104) 107) 108)}$ は, 応力成 長期の途中でせん断応力を解放して回復性ひずみ $\gamma e$ を直接測定 し，それから系の構造変化を推論したり， $E_{f}, E_{e l}$ および $E_{s t r}$ を 計算したりしている，その詳紐については，次回で述べるてとと する， $E_{s t r}$ は Malkin らの方法 ${ }^{104)}$ で求めるべきであると考えら れる。

\section{$3 \cdot 3$ 断 続 流 動}

定常せん断流動を時刻 $t=-t_{1}$ で一たん停止し， $t=0$ で再び開 始すると，応力は Fig. 3 のように変化する（せん断応力だけを 示す)．流動の停止および開始は瞬間的に行なうとし，停止前と 開始後のせん断速度を $\kappa$ とする．時間 $-t_{1} \leqq t<0$ においては，定 常流停止後の応力緩和も観測されるが，乙てでは $t \geqq 0$ における 応力成長だけを問題にする。応力 $\sigma_{s}\left(t, t_{1}\right)$ および $\sigma_{n}\left(t, t_{1}\right)$ が極 大になる時間 $t_{m}{ }^{s}\left(t_{1}\right), t_{m}{ }^{n}\left(t_{1}\right)$ が，前項で述べたストレス・オーバ ーシュートの場合と同様に求まる。

$\mathrm{RR}$ と $\mathrm{SS}$ モデルでは，中断時間 $t_{1}$ は応力の中で $\{1-\exp (-$ $\left.\left.t_{1} / \tau_{i}\right)\right\}$ という形で含まれ， $t_{1}$ が $\tau_{i}$ に比べて小さいときはその影 響が顕著であって，応力のオーバーシュートを非常に小さくする ととがわかる. StSt モデルの場合も， $t_{1}$ は指数関数の中に含ま れて同様のととがいえる ${ }^{50)}$. この結論は, Trapeznikov ら ${ }^{95)}$,

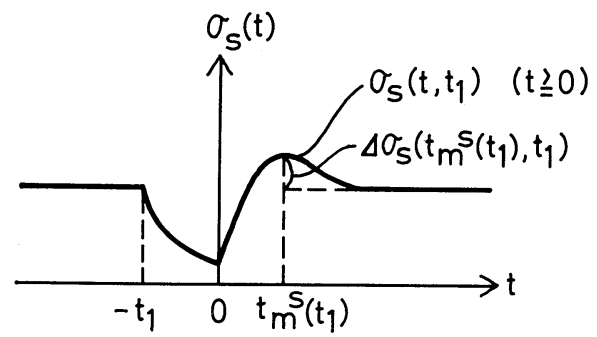

Fig. 3. A schematic representation of the interrupted flow. (Only the shear stress is shown). 


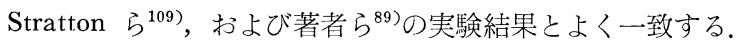

時刻 $t$ における值と定常值との差を $\Delta$ によって表わすととにす る. 例えば $\Delta \sigma_{s}\left(t, t_{1}\right)$ は,

$$
\Delta \sigma_{s}\left(t, t_{1}\right)=\sigma_{s}\left(t, t_{1}\right)-\kappa \eta(\kappa)
$$

である. Stratton ら ${ }^{109)}$ は，次式を満たす $t_{1}$ として $t_{e}^{s}$ を定義し， この值からからみ合い網目構造の回復の速さがわかると主張して いる.

$$
\frac{\Delta \sigma_{s}\left(t_{m}{ }^{s}\left(t_{1}\right), t_{1}\right)}{\Delta \sigma_{s}\left(t_{m}{ }^{s}(\infty), \infty\right)}=1-e^{-1}
$$

乙てで, $\Delta \sigma_{s}\left(t_{m}{ }^{s}\left(t_{1}\right), t_{1}\right)$ は応力の極大值から定常值を差し引いた ものであり (Fig. 3 参照)， $\Delta \sigma_{s}\left(t_{m}{ }^{s}(\infty), \infty\right)$ は前項に述べた通 常のストレス・オーバーシュートにおけるてのような応力差であ る. $\mathrm{RR}$ モデルでは, $\Delta \sigma_{s}\left(t, t_{1}\right)$ が

$$
\Delta \sigma_{s}\left(t, t_{1}\right)=\kappa \sum_{i} \Delta \tilde{\eta}_{i}(t, \kappa) \cdot\left\{1-\exp \left(-\frac{t_{1}}{\tau_{i}}\right)\right\}
$$

のように表わせるととから， $t_{e}^{s}$ は種々の緩和モードからの寄与 を平均した単なる見掛けの緩和時間に過ぎないととがわかる。

後に示すように，単分散高分子の系では，理論的にも実験的に も $t_{m}{ }^{s}\left(t_{1}\right) \fallingdotseq t_{m}{ }^{s}(\infty)\left(=t_{m}{ }^{s}\right)$ が成立する. このととと式(58)から， $\mathrm{RR}$ モデルで，同一の $\kappa$ に扔て

$$
t_{e}^{s} \neq t_{r}^{s}
$$

となることが示せる．乙こで， $t_{r}{ }^{8}$ は定常流停止後の応力緩和に おける見掛けの緩和時間であって, 次回総説〔II〕で定義する。 Stratton ら (分子量分布は未詳) ${ }^{109)}$ と著者ら (分子量分布は非常 に狭い ${ }^{89}{ }^{89}$ は， $t_{e}{ }^{s} \gg t_{r}{ }^{s}$ であるてとを実験的に見出している.

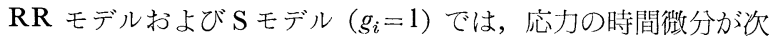
式で与觉られる。

$$
\begin{aligned}
& \frac{d \sigma_{s}\left(t, t_{1}\right)}{d t}=\kappa \sum_{i} \tau_{i} z_{i}^{*} a_{i} \cdot\left\{1-\exp \left(-\frac{t_{1}}{\tau_{i}}\right)\right\} \\
& \frac{d \sigma_{n}\left(t, t_{1}\right)}{d t}=\kappa^{2} t \sum_{i} \tau_{i} z_{i}^{*} \cdot\left(a_{i}+1\right) \cdot\left\{1-\exp \left(-\frac{t_{1}}{\tau_{i}}\right)\right\}
\end{aligned}
$$

(61)

式(60)，(61) と式(39)，(40)とを比較すればわかるように，乙れらのモデ ルでは, 単一緩和近似で

$$
t_{m}{ }^{s}, t_{m}{ }^{n} \text { は } t_{1} \text { によらない (62) }
$$

という結論が得られる。緩和時間に分布がある一般の場合には，

$$
t_{m}{ }^{s}\left(t_{1}\right)<t_{m}{ }^{s}(\infty), t_{m}{ }^{n}\left(t_{1}\right)<t_{m}{ }^{n}(\infty)
$$

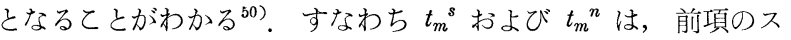
トレス・オーバーシュートの場合よりも短くなることになる。

SS モデル $\left(g_{i} \neq 1\right)$ の場合には，単一緩和近似をすると， $t_{m}{ }^{s}\left(t_{1}\right)>t_{m}{ }^{s}(\infty), t_{m}{ }^{n}\left(t_{1}\right)>t_{m}{ }^{n}(\infty)$ (64) となり, $t_{m}{ }^{s}$ は $t_{1}$ の增加とともに増加 $\rightarrow$ 極大 $\rightarrow$ 減少 $\rightarrow t_{m}{ }^{s}(\infty)$ と 変化することになる ${ }^{50)}$. StSt モデルの場合には， $t_{1}$ がごく短い ときだけ式(60)，(61)が近似的に成立する。

Trapeznikov ら $\left.{ }^{95}\right)$ はポリイソブチレン（分子量分布未詳）を用 いて実験し， $\kappa$ のあまり大きくないときは $t_{m}{ }^{s}$ が $t_{1}$ によらず， $\kappa$ の大きいときは $t_{m}{ }^{s}$ が $t_{1}$ の増加関数であるととを見出した. 分子量分布の非常に狭いポリスチレンを用いた著者らの実験結 果 ${ }^{89)}$ では, $t_{m}{ }^{s}$ は $\kappa$ の非常に大きい $\left(\kappa \tau_{m} \fallingdotseq 150\right)$ ときにも $t_{1}$ 亿依 存しなかった，単一緩和近似が単分散高分子に対して有効である

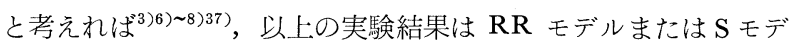
ルでよく説明され，SS モデルでは説明できないととになる。

（昭和 49 年 5 月 27 日，日本レオロジ一学会第 1 年会にて講演）

\section{文献}

1）倉田道夫，材料，21，360（1972）.

2）尾崎邦宏，高分子，22，563（1973）.

3）山本三三三，“物体の変形学"，(1972）誠文堂新光社.

4) Spriggs, T.W., J.D. Huppler, and R.B. Bird, Trans. Soc. Rheol., 10, 191 (1966).

5) Bogue, D.C., and J.L. White, "Engineering Analysis of Non-New tonian Fluids", (1971) NATO AGARDOGRAPH No. 114.

6) 山本三三三，材料，21，355 (1972).

7) Yamamoto, M., Appl. Polym. Symposia, 20, 3 (1973); 材料, 22, 400 (1973).

8）高橋雅興, 升田利史郎, 小野木重治, 日本レオロジ一学会誌, 1, 16 (1973).

9) Lodge, A.S., "Elastic Liquids", (1964) Academic Press, London-New York.

10) Lodge, A.S., Rheol. Acta, 11, 106 (1972).

11) Lodge. A.S., and J.H. Stark, ibid., 11, 119 (1972).

12) White, J.L., and A.B. Metzner, J. Appl. Polym. Sci., 7, 1867 (1963).

13) Oldroyd, J.G., Proc. Roy. Soc., (London), A200, 523 (1950).

14) Oldroyd, J.G., ibid., A245, 278 (1958).

15) Williams, M.G., and R.B. Bird, Phys. Fluids, 5, 1126 (1962) ; Ind. Eng. Chem. Fund., 3, 42 (1964).

16) Spriggs, T.W., Chem. Eng. Sci., 20, 931 (1965).

17) Goleman, B.D., and W. Noll, Ann. N.Y. Acad. Sci., 89, 672 (1961).

18) Tanner, R.I., and J.M. Simmons, Chem. Eng. Sci., 22, 1079 (1967).

19) Doughty, J.O., and D.C. Bogue, Ind. Eng. Chem. Fund., 6, 388 (1967).

20) Arnold, K.R., and J.R. Street, "Proc. 5th Int. Cong. Rheol.”, 4, 377 (1970) ed. by S. Onogi, Univ. Tokyo Press.

21) Spearot, J.A., and A.B. Metzner, Trans. Soc. Rheol., 16, 495 (1972).

22) Leider, P.J., and L.U. Lilleleht, ibid., 17, 501 (1973).

23) Joye, D.D., G.W. Poehlein, and G.D. Denson, ibid., 17, 287 (1973).

24) McKelvey, J.M., "Polymer Processing", (1962) John Wiley, New York.

25) Truesdell, G., and W. Noll, "The Non-Linear Field Theories of Mechanics" in "Handbuch der Physik", VIII, Part 3, (1965) Springer-Verlag, Berlin.

26) Goleman, B.D., H. Markovitz, and W. Noll, "Viscometric Flows of Non-Newtonian Fluids", (1966) Springer-Verlag, Berlin.

27) Goleman, B.D., and W. Noll, Arch. Rat. Mech. Anal., 3, 289 (1959) ; 6, 355 (1960).

28) Goleman, B.D., and W. Noll, Rev. Mod. Phys., 33, 239 (1961) ; 36, 1103 (1964). 
29) Green, A.E., and R.S. Rivlin, Arch. Rat. Mech. Anal., 1, 1 (1957).

30) Green, A.E., R.S. Rivlin, and A.J.M. Spencer, ibid., 3, 82 (1959).

31) Green, A.E., and R.S. Rivlin, ibid., 4, 387 (1960).

32) Pipkin, A.C., Rev. Mod. Phys., 36, 1034 (1964).

33) Nakada, O., J. Phys. Soc. Japan, 15, 2280 (1960).

34) White, J.L., J. Appl. Polym. Sci., 8, 1129 (1964).

35) White, J.L., ibid., 8, 2339 (1964).

36) Yamamoto, M., J. Phys. Soc. Japan, 25, 239 (1968).

37) Yamamoto, M., Trans. Soc. Rheol., 15, 331 (1971).

38) Bird, R.B., and P.J. Carreau, Chem. Eng. Sci., 23, 427 (1968).

39) Tanaka, T., M. Yamamoto, and Y.Takano, J. Macromol. Sci., (Phys.) B4, 931 (1970).

40) Bernstein, B., E.A. Kearsley, and L.J. Zapas, Trans. Soc. Rheol., 7, 391 (1963) ; 9, 27 (1965).

41) Zapas, L.J., J. Res. Natl. Bur. Stand., 70A, 525 (1966).

42) Bogue, D.C., and J.O. Doughty, Ind. End. Chem. Fund., 5, 243 (1966).

43) Adams,E.B., and D.C. Bogue, AIChE J., 16, 53 (1970).

44) Zapas, L.J., and J.C. Phillips, J. Res. Natl. Bur. Stand., 75 A, 33 (1971).

45) Chen, I-J., and D.G. Bogue, Trans. Soc. Rheol., 16, 59 (1972).

46) David, J., Rheol. Acta, 11, 333 (1972).

47) Carreau, P.J., Trans. Soc. Rheol., 16, 99 (1972).

48) Meister, B.J., ibid., 15, 63 (1971).

49）中村 良, 吉岡直哉, 木村松弘, 材料, 20，643 (1971).

50) Takahashi, M., T. Masuda, and S. Onogi, to be published.

51) Kaye, A., Brit. J. Appl. Phys., 17, 803 (1966).

52) Marrucci, G., G. Titomanlio, and G.C. Sarti, Rheol. Acta, 12, 269 (1973).

53) Lodge, A.S., Rheol. Acta, 7, 379 (1968).

54) Lodge, A.S., Trans. Faraday Soc., 52, 120 (1956).

55) Yamamoto, M., J. Phys. Soc. Japan, 11, 413 (1956) ; 12, 1148 (1957) ; 13, 1200 (1958).

56) Bogue, D.C., Ind. Eng. Chem. Fund., 5, 253 (1966).

57) Chen, I-J., G.E. Hagler, L.E. Abbott, D.C. Bogue, and J.L. White, Trans. Soc. Rheol., 16, 473 (1972).

58) Tanner, R.I., J.M. Simmons, Chem. Eng. Sci., 22, 1803 (1967).

59) Tanner, R.I., Trans. Soc. Rheol., 12, 155 (1968).

60) Tanner, R.I., AIChE. J., 15, 177 (1969).

61) McGuirt, G.W., and G. Lianis, "Proc. 5th Int. Gong. Rheol.”, 1, 337 (1969) ed by S. Onogi, Univ. Tokyo Press ; Trans. Soc. Rheol., 14, 117 (1970).

62) Goldberg, W., and G. Lianis, J. Appl. Mech., 35, 433 (1968) ; 37, 53 (1970).

63) Yuan, H-L., and G. Lianis, Trans. Soc. Rheol., 16, 615 (1972).

64) Meissner, J., Trans. Soc. Rheol., 16, 405 (1972).
65) Mancke, R.G., and R.F. Landel, J. Polym. Sci., A2, 10, 2041 (1972).

66）高分子学会編，“高分子実験学”，物性 1.力学的性質 I , 第 2 章, 共立出版, 発行予定.

67) Sakai, M., H. Fukaya, and M. Nagasawa, Trans. Soc. Rheol., 16, 635 (1972).

68) Sakai, M., H. Kajiura, and M. Nagasawa, ibid., 18, 323 (1974).

69) Meissner, J., J. Appl. Polym. Sci., 16, 2877 (1972).

70) Huppler, J.D., I.F. Macdonald, E. Ashare, T.W. Spriggs, R.B. Bird, and L.A. Holmes, Trans. Soc. Rheol., 11, 181 (1967).

71) Rokudai, M., and T. Fujiki, Appl. Polym. Symposia, 20, 23 (1973).

72) Kajiura, H., H. Endo, and M. Nagasawa, J. Polym. Sci., A2, 11, 2371 (1973).

73) Stratton, R.A. J. Colloid Interface Sci., 22, 517 (1966).

74) Graessley, W.W., and L. Segal, AIChE J., 16, 261 (1970).

75) Endo, H., T. Fujimoto, and M. Nagasawa, J. Polym. Sci., A2, 9, 345 (1971).

76) Sakai, M., T. Fujimoto, and M. Nagasawa, Macromol., 5, 786 (1972).

77) Graessley, W.W., and L. Segal, ibid., 2, 47 (1969).

78) Sakai, M., I. Noda, and M. Nagasawa, J. Polym. Sci., A2, 10, 1047 (1972).

79) Graessley, W.W., J. Chem. Phys., 43, 2696 (1965).

80) Graessley, W.W., ibid., 47, 1942 (1967).

81) Graessley, W.W., R.L. Hazleton, and L.R. Lindeman, Trans. Soc. Rheol., 11, 267 (1967).

82）尾崎邦宏，太田伸一，金 鳳植，福田三寿，倉田道夫，第22 回レオロジ一討論会講演予稿集 p. 63 (1974).

83) Onogi, S., T. Masuda, I. Shiga, and F.M. Costaschuk, Appl. Polym. Symposia, 20, 37 (1973).

84) Olabisi, O., M.G. Williams, Trans. Soc. Rheol., 16, 727 (1972).

85) Ginn. R.F., and A.B. Metzner, ibid., 13, 429 (1969).

86) Miller, M.J., and E.B. Ghristiansen, AIChE J., 18, 600 (1972).

87) Christiansen, E.B., and W.R. Leppard, Trans. Soc. Rheol., 18, 65 (1974).

88) Osaki, K., Y. Einaga, N. Yamada, and M. Kurata, Polym. $J .$, 6, 72 (1974).

89) Takahashi, M., T. Masuda, and S. Onogi, to be published.

90) van Es, H.E., R.M. Ghristensen, Trans. Soc. Rheol., 17, 325 (1973).

91) Lodge, A.S., and J. Meissner, Rheol. Acta, 12, 41 (1973).

92) Nishida, N., D.G. Salladay, and J.L. White, J. Appl. Polym. Sci., 15, 1181 (1971).

93) Trapeznikov, A.A., "Proc. 5th Int. Gong. Rheol.", 4, 257 (1970) ed. by S. Onogi, Univ. Tokyo Press.

94) Vinogradov, G.V., and I.M. Belkin, J. Polym. Sci., A3, 917 (1965). 
95) Trapeznikov, A.A., and A.T. Pylayeva, Vysokomol. soyed., A12, 1294 (1970).

96) Trapeznikov, A.A., and A.T. Pylayeva, ibid., A10, 1539 (1968).

97) Schurz, J., and A. Mavrommatakos, Angew. Makromol. Chem., 15, 95 (1971).

98) Middleman, S., Trans. Soc. Rheol., 13, 123 (1969).

99) Osaki, K., Y. Einaga, N. Yamada. S. Ohta, and M. Kurata, Polym. J., 6, 165 (1974).

100) Einaga, Y., K. Osaki, M. Kurata, S. Kimura, and M. Tamura, ibid., 2, 550 (1971).

101) Einaga, Y., K. Osaki, M. Kurata, S. Kimura, N. Yamada, and M. Tamura, ibid., 5, 91 (1973).

102）尾崎邦宏，太田伸一，福田三寿，倉田道夫，日本レオロシ 一学会第 1 年会講演予稿集 P. 7 (1974)
103）尾崎邦宏，福田三寿，倉田道夫，第23回高分子討論会講演 要旨集 p.461 (1974).

104) Malkin, A. Ya., B.V. Yarlykov, and G.V. Vinogradov, Rheol. Acta, 9, 329 (1970).

105) Lewis, W.E. and R.S. Brodkey, "Proc. 5th Int. Cong. Rheol.", 4, 141 (1970) ed. by S. Onogi, Univ. Tokyo Press.

106）梶浦博一, 逆井基次, 永沢 満, 日本レオロジ一学会第 1 年会講演予稿集，P. 3 (1974)

107) Vinogradov, G.V., A. Ya. Malkin, M.P. Zabugina, and V.F. Shumskii, Vysokomol. soyed., A11, 1221 (1969).

108) Vinogradov, G.V., A. Ya. Malkin, V.F. Shumskii, and M.P. Zabugina, ibid., A11, 2002 (1969).

109) Stratton, R.A., and A.F. Butcher, J. Polym. Sci., A2, 11, 1747 (1973). 